\title{
Validity and Legal Protection of Defendant in an Online Trial System
}

\author{
Raja Mohamad Rozi ${ }^{1, *}$, Nisya $^{1}$ \\ ${ }^{1}$ Research and Development Centre of The Republic of Indonesia Prosecutor's Office, Jakarta, Indonesia \\ *Corresponding author. Email: rozi.sui.iuris@gmail.com
}

\begin{abstract}
One of the functions of criminal procedural law is to enforce material law. The point is to reveal the material truth. Since it was enacted, the criminal procedure code has not been separated from the "test" of its application. The various kinds of exercise include: professionalism of law enforcement, challenges to Indonesia's geographic areas, and the issue of the Covid 19 Pandemic. The Covid 19 outbreak has an impact on the implementation of a criminal proceeding, therefore it creates an obstacle for the meeting of parties in an open and fairly criminal justice system. The Attorney General's office through the Attorney General instruction No. 5 of 2020 mandates all levels of prosecutors to conduct hearings by teleconference. The online trial also approved by Supreme Court with Supreme Court Circular Letter (SEMA) No. 1 of 2020 concerning Guidelines for implementing tasks during the prevention period of the spread of Covid 19. Based on this, there are conflicting rules. In Articles 11 and 12 of Law Number 48 of 2009 concerning judicial power, the trial is attended by 3 (three) judges assisted by the registrar, the public prosecutor, and the defendant who must be present in the court building room. This obligation is also regulated in several provisions of Articles 154, 159, 196, 227 (2), and 230 (1) and (2) of the Criminal Procedure Court. Based on this, the main problems are: (i) What is the validity of the teleconference/online trial according to legislation? (ii) What is the aspect of legal protection for the accused in the trial process? The research method used is juridical normative by analyzing legal materials against legal concepts and norms in a qualitative and prescriptive manner. The purpose of the research is (i) to find the legal validity of teleconference/online trial, (ii) to find the legal protection of the defendant in the teleconference/online trial process. This research resulted in: (i) Although the validity of the teleconference/online trial is not clear and clean, it is a way out for delay of justice; (ii) The legal protection of the defendant can be provided according to the minimum standards stipulated by the criminal procedure code. Since the Covid 19 Pandemic uncertain, law enforcement must continue and creativity is needed. We suggest that Perpu No. 1/2020 should also contain mechanisms for criminal proceedings to ensure legal certainty.
\end{abstract}

Keywords: Online trial, Validity, Legal Protection.

\section{INTRODUCTION}

Online criminal trials are not new to the justice system in Indonesia, the government has long been organizing online trials.

This trial system has been introduced under the name E-Court based on - PERMA No. 1 of 2019 applies to commercial courts, where the parties register, pay the case (e payment), call (e-summon), file (e-filling) online.
The basic for these regulations is Presidential Decree 11 of 2020 (PSBB) and Keppres 12 of 2020 Covid-19 as a National Disaster.

Initially, the need for online criminal trials was due to the Assimilation Policy through Permenkumham No. 10 of 2020, namely 38,822 prisoners release.

This policy contains the intention of dealing with overcapacity to prevent the transmission of Covid-19 into prisons. This policy was followed by not requiring the mobility of detainees from the 
police and prosecutors to prison for the sake of proceeding in court.

This situation certainly requires a quick response, especially from the public prosecutor who must delegate cases to court proceedings. The Attorney General's Office through the Attorney General's Instruction No. 5 of 2020 mandates all levels of prosecutors to conduct hearings via teleconference. As a test case, this system is the trial of minor criminal cases at the Riau High Prosecutor's Office, namely for cases of violations of the PSBB where each party, namely the perpetrator and law enforcement, interacts via virtual. However, there are still big cases such as corruption of PT. Jiwasraya where the defendant Benny Tjokro et al were tried directly at the Corruption Crime Court.

In criminal proceedings on line Judges / Panel of Judges, court clerks in the courtroom. Public Prosecutors, Legal Counsels, and Defendants, Experts, Witnesses were virtually present at the trial on the network from different places at the same time. Calls and notifications are no longer met in person / in person, but electronically. This means that there is a shift in legal domicile to electronic domicile, and there is a shift in the jurisdiction.

This year, until April 30, 2020, the case handling performance of the Criminal Chamber recorded 2,364 criminal cases, plus the remaining cases last year reached 2,577 cases, 1,455 cases were decided and $64.73 \%$ of cases had not been transferred. As of April 30, 2020, the overall case burden (criminal, civil, state administration, religious) of the Supreme Court reached 8,732 cases and just $55.37 \%$ of cases were decided with the remaining cases of 3,897 cases [1].

With this in mind, the online criminal trial also received approval from the Supreme Court through SEMA No. 1 of 2020 concerning "Guidelines for Implementing Tasks During the Prevention Period of the Spread of Covid19 below. There are various reasons why the Supreme Court is also responsive, due to the working mechanism that has changed according to the work from home policy and the fact that (i) the trial will continue to be held; (ii) the trial is adjourned; (iii) the examination is postponed with a trial report (extraordinary circumstances). Whereas so far, the best practice is that E-Litigation for civil cases, religious matters, and state administration has started to take effect.
There are several articles in Law Number 48 of 2009 concerning Judicial Power, namely Article 11 and Article 12. It states that the trial is attended by 3 (three) Judges assisted by the Registrar.

The Public Prosecutor is obliged to attend, the Defendant must attend and several articles in the Criminal Procedure Code.

a. The defendant was present (Article 154, 196 of the Criminal Procedure Code).

The witness was present at the trial (Article 159 of the Criminal Procedure Code).

b. Expert: What was stated at the Session = Present.

The presence of the parties mentioned above is physical presence as stipulated in Article 227 paragraph (2) Summons and Notifications, meet alone or in person. Then in Article 230 paragraph (1) and (2) KUHAP, the court session is held at the court building in the courtroom, where Judges, Public Prosecutors, Legal Counsel, and Clerk wearing court clothes and their respective attributes.

Legal issues that have surfaced are regarding the validity and protection of defendants who face court proceedings online. There was concern that the mechanization of the on-line trial had procedural flaws and the defendant's legal protection may be violated by law enforcement.

\section{RESEARCH METHOD}

This research is conducted by juridicalnormative method which analyses secondary data from primary law materials. The primary law materials are constitution, act, and any regulations concerned to providing the court and law protection, i.e. UUD 1945, KUHAP, Law Number 48/2009 concerning Judicial Power, PP No.27/1983 or PP No. 92/2015 has conflicted with SEMA No. 1/2020 concerning on line trial. The secondary law materials consists of literature, journal, and dictionary related to the problems persisted on this research. This research does not only compile the materials such as theories, law concepts, principles, and regulations of law dealing with the topic, but also explains the reality of the law in prescribe as a positive law for the subject, that is the defendant with limited law protection. All data needed are collected by reviewing the literature. The facts are identified, as in the identification of the raw material sources. 
Following this, the law materials will be analyzed qualitatively by doing in-depth analysis to be synthesized.

\section{FINDINGS AND DISCUSSION}

As the Covid-19 pandemic is has brought radical changes in all global and domestic fields, government policies regarding pandemics include Large-scale implementation of social distancing, using masks (wearing masks), doing work and school in a virtual way (virtual work/school), preventing the gathering of people (banned group gatherings)

This situation certainly requires a quick response from law enforcements, especially from the public prosecutor who must delegate cases to court proceedings.

\subsection{Online Criminal Court administration and Rule of Law}

On the juridical-empirical side of the Covid-19 pandemic era, there are different considerations such as the limited period of detention, concerns about the loss of evidence, and the possibility of this pandemic will end and it is difficult to predict when it will terminate so that conventional trial may resume to normal. The first two considerations relate to the legal aspect, namely that detainees can be free by law, then the loss and damage of evidence can weaken the evidence. The final consideration is the concern that the transmission of covid-19 is increasing.

This criminal justice breakthrough event [2] is not known in the Criminal Procedure Code. In criminal procedural law, the most important matter is to reveal the material truth, whether a criminal incident committed it, in what way, what is the consequence and who is the victim, then there is no excuse for forgiveness and justification, which is known as the excuse of criminal offense (strafuitsluitingsgronden and rechtvaardigingsgronden) on the side of the perpetrator and his actions [3].

On the technical side, it is feared that communication between the parties involved will not be optimal, namely constrained by an unstable internet network in the end, the proof is not maximal at this online criminal trial. The essence of a criminal trial is the search for a material truth that is closely related to legal certainty (recht zakerhieid).

In the concept of rule of law, a country is said to be a state based on law, at least in its legal and judicial systems that recognizes procedural due process and substantive due process principles [4]. Substantive due process is an understanding that the legislature issues various kinds of laws that regulate all aspects of life, including laws in the criminal field, such as: the Criminal Code and other laws in the field of criminal and criminal procedural law is the procedure for determining the content and the procedure for making laws. While procedural due process is procedures for implementing and enforcing the law.

The three factors balance test of trial mechanization on has established a procedural due process to demand that the court must: (i) "personal interests that will be affected by the actions of officials"; (2) "The risk of misappropriation of said interest through the procedures used, and the probable value, if any, of additional or surrogate procedural protections", and (3) "the interests of the government, including the functions involved and administrative and tax / fiscal burdens. Increments or substitute procedural requirements that will be required [5].

The Attorney General's Instruction and Supreme Court Circular have drawn criticism because they are not externally applicable regulations and do not bind defendants and legal advisers and are not the result of legislation. This argument is emphasized because one of the legislating functions according to the separation of powers theory introduced by Monstesque and John Locke is to prevent tyranny in an axis of power in which the legislators cannot concurrently act as an institution implementing laws, because would violate the principle of check balances of power.

Law Number 8 Year 1981 regarding the Criminal Procedure Code is a legislating product that provides procedural provisions on how substantive criminal law is enforced in court. Even in the preamble and general explanation of the law there is the purpose of the legislation, which is to reveal the material truth and lead to legal certainty.

The Ratio legis of the provision make sense because it do not talk about the issue of justice but the issue of legal certainty at first. The essence of legal certainty that will be sounded in chapter by chapter of the Criminal Procedure Code contains method procedures, rights and obligations of law enforcers, criminal offender, and victims and confiscation of property and freedom of criminal offender and this is one of the characteristics of the rule of law described by Openheim [6]. This means that the substance of procedural law, the first and 
foremost priority is the side of legal certainty to realize justice.

Criminal law policies and their enforcement during the Covid period were still partial and not yet integrated. With the Supreme Court providing a Circular or Supreme Court Regulation regarding online trials, it means that the Supreme Court can have a dual function, namely on the one hand implementing laws but on the other hand issuing "laws". In his opinion, the Supreme Court regulation is equal to the executive action, meaning that it is similar to the Attorney General's Regulation and other institutions because the product is made unilaterally (enzijdige), not within the capacity of the object of 3 (three) parties testing like a court decision. Its enforcement can indeed come out as other institutional regulations, but whether the Perma cannot be tested or rejected or ignored, when the Perma contradicts the law, namely the KUHAP.

Cekli argued that: "Internal E-court and Elitigation policies are only based on PERMA and SEMA which only bind internally within the Supreme Court and the Judicial Bodies below, then how to synergize with other law enforcement functions such as prosecutors, police, advocates?". This expert further questioned: "Why could the government make a Covid-19 legislation but also fail to make a KUHAP legislation. Is not that necessary to change procedural procedures to guarantee the principle of legal certainty, so that the Criminal Procedure Code needs to be revised or it can also be through the KUHAP legislation" [7].

In general, E-litigation (online trial) is prioritized for civil cases, religious cases, and state administration cases. It has not been optimally applied to criminal justice, so it is not sufficient to guarantee the realization of a 'fair trial'. Meanwhile, some criminal cases still use off-line trials --- the unequal treatment of every citizen is only due to unsupported technical readiness. There are a small number of courts that use teleconferences in criminal justice - the main emphasis of which is on "the principle of fast, simple, and low-cost trial, but neglects the aspect of" the importance of finding material truth ". Problem examining witnesses, proving, and legal assistance at every level of examination cannot be fulfilled optimally through a teleconference.

The potential for the practice of torture, the intensity of arbitrary detention tends to increase during the Covid-19 Pandemic due to the application of Discretionary powers. Meanwhile CAT ratified by Indonesia has not been adopted by the Criminal Procedure Code [7].

However, to prevent the transmission of covid19 , online criminal trials can be a solution to save human lives from direct contact in one room between the defendant, public counsel, legal advisor, and judge. Lawyers, along with prosecutors and court officials, and many others, are determined to adapt quickly to provide justice during Covid-19, including delivering it remotely.

There is an online trial option that can quickly minimize the transmission of covid-19 by not mobilizing people with the following scheme: first option; the defendant remains in the detention center, while the public prosecutor, witnesses, and legal advisers stay at the District Prosecutor's Office, then a panel of judges at the District Court. Second option; the defendant is in the detention center, while the prosecutor is at the District Attorney, the panel of judges at the District Court, then the witness / legal adviser at their respective residences. The third option would be keeping the defendant in the detention center, while the panel of judges, public prosecutors, and witnesses are at the District Court [8].

Although on the one hand, the online trial mechanism is based on low provisions under the law and is based on inadequate legal provisions, there is a potential for the possibility to be rejected due to juridical flaws. We recommend that if the Covid-19 pandemic continues beyond 2020, the government must take the initiative to release a Government Regulation in Lieu of a Law on Criminal Procedure Code. The substance can take over the draft Criminal Procedure Code that has been formed previously, then add a clause on force majeure that adopts online trials for anticipation.

\subsection{Implementation of the Criminal Session On line and Protection of Human Rights.}

The implementation of the on line trial involves an integrated criminal justice system. This Integrated Criminal Justice System covers all functions and institutions of the judiciary from the examination stage to the correctional facility.

In the current integrated criminal justice system, namely the KUHAP era, every examination system that is enforced is accusatorial. Where the due process model applies. The purpose of the criminal justice system is to deal with criminal defendants fairly and in accordance with constitutional standards in which Articles 27 and 28 of the 1945 Constitution emphasize the protection of human 
rights. Then, for a long time, the Criminal Procedure Code should also provide protection to suspects through the implementation of Article 56, namely respecting individual rights and dignity in the face of state power, not only the suppression of crimes.

KUHAP adheres to the due process model that rejects informal fact-finding administration and adjudication preferences that take a position opposite to the formal process. In the due process model, there are no valid facts findings until the case is openly tried and evaluated by a fair court, and the defendant has had the full opportunity to discredit the case against him [8]. The characteristic of the due process model is the protection of the suspect's rights to determine whether a crime is proven and the guilt of a person who has to go through a trial.

The online criminal trial raises a dialectical question of whether to reduce the protection of human rights because the system in effect turns on the crime control model system based on the assumption of a value system that presents repressive action on crime as the most important function in a Criminal Justice System.

Cekli argues that there is a kind of strengthening of the CCM, while the Criminal Procedure Code itself has not adopted human rights values optimally (ICCPR, CAT). Law enforcement officials who have the potential to violate human rights during the PSBB increase. In Kontras Records (arbitrary arrests (17 cases), arrests on charges of insulting state officials ( 8 cases), critics mixed with hoaxes (41 cases), as well as problems with access to legal aid. Again placing society as a "state enemy" that must be approached by means of repression and punishment, rather than through increasing legal awareness of the importance of understanding the dangers of hoaxes and others. Various forms of handling freedom of opinion tend to cause fear in society rather than creating a legal order. It is necessary to distinguish between criticism and news dissemination to advocate hatred for certain groups. This is counterproductive to the government's efforts to reduce the number of prisoners to prevent the spread of Covid 19 [8].

According to the Crime Control Model, the aim of the Criminal Justice System is to suppress crime, which is controlled through the imposition of criminal sanctions against convicted defendants. To achieve this goal, the Crime Control Model states that the main concern must be directed efficiently. Efficiency includes speed, thoroughness, and administrative efficiency in processing criminal offenders. Every job must be done quickly and must be finished immediately. Therefore, the process should not be interrupted by a series of unnecessary ceremonies and minimize any resistance from other parties as this only hinders the settlement of cases.

The principle of simple justice and low cost (contante justitie) has always been the main reason for implementing online trials during the the Covid19 pandemic. This means that there is a desire for the CCM to be revived, even though so far the implementation of the Criminal Procedure Code has not been optimal due to geographical challenges and resource challenges so that often criminal procedural law procedures are not fully and completely implemented. There has been much criticism from the public regarding this as if the rights of suspects and defendants and even convicts who do not understand the law will be easily ignored.

Effective SPP paradigm, in the crime control model it will be assumed by law to be presumption of guilt, which means allowing the pre-judgment of guilt (and ultimately preventive in the form of detention or imprisonment) to be convicted of certain suspects. In fact, to say that if governments invested in public power - initiate investigations into certain individuals and as a result decide that sufficient evidence has been gathered to bring them to trial, it must be presumed that the individual is guilty in this respect (presumption of). guilty), and it is the suspect/defendant's responsibility/right to refute this and present evidence to the contrary [9].

The argument that the holding of on-line trials is not directly facing the parties, similar to CCM which has reduced the rights of suspects, has also been put forward by Herbert L. Packer that the doctrine used by the crime control model is what is known as the presumption of guilt [9]. The legal umbrella for online criminal proceedings is associated with the identical CCM doctrine, which emphasizes the importance of affirming the existence of power and the use of power against every crime and criminal, and therefore the exercise of the use of power in the hands of government officials (police, prosecutors and judges) must be as much as possible even though it must sacrifice rights Human Rights, for example, acts of violence.

Indonesia itself ratified the CAT convention through Law No. 5 of 1998 on September 28, 1998. Through this law, Indonesia also made a declaration on the provisions of Article 20 paragraph (1) paragraph (2) and paragraph (3) and made reservations for the provisions of Article 30 paragraph (1) of this convention. The text of Article 1 of the Convention against Torture puts forward an internationally agreed definition of acts that constitute "torture". This article stipulates that [9]: 
the term "torture" means any act which is done deliberately, causing great pain or suffering, both physically and spiritually, to a person to obtain a confession or information from that person or a third person, by punishing him for an act that has been committed or suspected, has been committed by that person or a third person, or threatened or coerced that person or a third person, or for any reason based on any form of discrimination, if the pain or suffering was caused by, at the instigation of, with the consent or knowledge of that person, public officials or other persons acting in a public capacity. It does not include pain or suffering that simply arises from an applicable legal sanction

The "essential elements" of what constitutes torture are contained in Article 1 of the Convention against Torture, which includes:[9]

- The occurrence of intense mental or physical pain or suffering;

- By or with the consent or knowledge of the competent State officials

- For a specific purpose, such as obtaining information, punishment or intimidation.

Cruel treatment and treatment or punishment that is inhuman or degrading to human dignity are also legal terms. These terms refer to ill-treatment which does not have to be inflicted for a particular purpose, but that there must be an intention to expose individuals to conditions equal to or result in illtreatment. Exposing a person to conditions that can be believed to be ill-treatment will lead to responsibility for the suffering caused. Treatment that is degrading human dignity can include pain or suffering that is not as intense as torture or cruel or inhuman treatment and will generally include humiliation and a decrease in the self-esteem of the victim[9].

The Indonesian state itself has ratified the ICCPR on October 28, 2005, through the law of the Republic of Indonesia Number 12 of 2005 concerning Ratification of the International Covenant On Civil And Political Rights (International Covenant on Civil and Political Rights)accompanied by a Declaration on Article 1 concerning Ratification of the International Covenant on Civil and Political Rights. Civil and Political Rights Include [9]:

1. The right to life

2. The right to be free from torture and inhuman treatment
3. The right to be free from slavery and forced labor

4. The right to freedom and personal safety

5. The right to freedom of movement

6. The right to recognition and equal treatment before the law

7. The right to freedom of thought, belief, and religion

8. The right to freedom of opinion and expression

9. The right to assemble an association

10. The right to participate in government

Several points related to the contents of the convention are linear with protection according to the provisions of Articles 50, 51, 52, 53, 54, 55, 56, 57, 58, 59, 60, 61, 62, 63, 64, 66, 67, 68, 72, 177, 178, 244 and 263 of the Criminal Procedure Code, among others [10]:

1. The right to be accompanied by a translator.

2. The right is not subject to an obligation of proof.

3. The right to freely give information without fear of physical and psychological threats.

4. Right to present mitigating witnesses.

5. The right to ask questions.

6. The right to an impartial trial.

7. The right to be released free if the charges are not proven.

8. The right to be cut off from all lawsuits if the charges are proven but not a criminal act.

9. The right to be released from detention if he is freed and free from all charges.

The Constitution has also guaranteed that in accordance with the provisions of Article 28D paragraph 1 of the 1945 Constitution, it reads: "Everyone has the right to recognition, guarantees, protection and legal certainty that is just and equal treatment before the law". The Constitution has provided normative protection for every person, including suspects, defendants, and convicted people in a more general perspective as follows [7]:

a. The right to freedom of opinion and association.

b. The right to public health to the highest standards.

c. The right to equal treatment.

d. Right to non-discriminatory treatment.

e. Right to get a fair trial.

f. The state as the duty bearer and the person as the right holder (state as the duty bearer and individual as the right holder). 
Online criminal proceedings have the potential to neglect the constitutional rights of citizens, both those directly involved in the case and potentially in it. Whereas in the International Framework to create a superior judiciary, there are 7 (seven) good judicial parameters as this measurement tool has been used by the Supreme Court to accredit all courts in Indonesia [7].
a. Judicial management and leadership.
b. Role of the judiciary and court policy
c. Human Resource Management
d. The trial process is fast and low cost.
e. The need or satisfaction of court services.
f. Access and Affordability.
g. Public trust and conviction.

Based on the fact that all this time, there is a criminal proceedings are carried out not at the right time, such as in the afternoon, or when the media is in absence, then in the judge's room and not accompanied by a legal advisor. This is the result of research on a dissertation defended by Fachmi at Padjadjaran University, Bandung. This kind of trial will certainly give birth to court decisions that are null and void. The quality of the on-line trial mechanism will be null and void because it escapes public scrutiny.

Gary Goodpasters, argues in Tim Lindsa edits (ed)., Law Reform in Developing and Transitional States (2007) is clearly stated "Today, the Indonesian legal system cannot be trusted - indeed, cannot be used to render honest decisions - but may. be trusted to protect corrupt activities. By all accounts, the Indonesian legal system.... is wretched $"[1]$.

According to [11] Shinta Ayu Purnamawati, KUHAP is a microsystem consisting of Police Attorney - Court - LAPAS - Advocates / Legal Advisors, while the macro system is Law Institutional - Financial - Cultural - Geographical Political - SARA - Education - Economy. The principles of an integrated criminal justice system must be Free / Cheap, Simple, Fast, Complete, Transparent, Accountable, Fairness and Certainty, Justice, Benefit. The essence of the hope of the functioning of the criminal justice system in the context of the micro and macro systems must be realized as follows [7]:

a. Justice management and leadership --(Access to justice for all)

b. Role of the judiciary and court policy

c. Human Resource Management Understanding human rights values for law enforcement officials d. The trial process is fast and low cost. This should not diminish the essence of seeking material truth in criminal cases.

e. The need or satisfaction of court services. Court services through ecourt or e-litigation must lead to client satisfaction with judicial processes, procedures, and services. The openness of public access to court processes, procedures, and services must be measured and continuously improved.

f. Access and Affordability. Courts must take into account that there are vulnerable or marginalized groups such as people with disabilities (with special needs), the poor, minority groups and ensure that they have equal access to justice.

g. Public trust and conviction. Public participation in judicial oversight.

The covid-19 condition is a state of force. The state of force (overmacht or force majeure) according to Black Law's Dictionary is "an event or effect that can be neither anticipated nor controlled. So it can be understood that "a state of force is a situation beyond human control that occurs". In such force majeure condition, according to the procedural law, a criminal case cannot be resolved in court through normal mechanisms. An abnormal situation requires creativity to solve criminal cases through the online criminal justice system. The requirements above should be fulfilled so that legal certainty, justice, legal benefit, and fair trial is implemented

The condition of Covid-19 creates norm tension in the judicial administration system where the objectives of justice and protection of human rights are at stake, while "solus populi suprema lex" (people's safety is the highest law). For justice and protection of human rights to be fulfilled, legalization of online trials can be pursued by:

a. Making the special rules for the law provision of teleconference sessions or creating the Criminal Procedure Code perpu as an excuse for force majeure as the urgency to force the realization of legal certainty.

b. Expanding the justice system is not only criminal but not limited to absolute competence but also relative competence throughout Indonesia with a set time limit.

c. Targeting the accumulated case settlement process and bound by time 
limits according to legal provisions such as detention and evidence to prevent delay in justice.

d. Integrating systems, procedures and means and pre-trial facilities that can be accessed by the public, except for juvenile and immoral cases, so that the gesture of all parties involved can be seen virtually, including evidence that is shown in front of the trial online.

e. Establishing rules enforcing minimum standards according to the procedural law of examination and evidence in the Criminal Procedure Code.

However, some criteria must be met to ensure that the aspects of impartiality and fairness, and accountability of an on-line trial:

a. This technology will not be used for cases that are difficult to prove such as corruption and money laundering, and judges will decide whether it is appropriate for use in other trials on a case-by-case basis.

b. Many of the trials continue to be conducted by judges who sit in court and aim to reopen the courts that have been temporarily suspended during the Covid-19 period as quickly as possible.

c. Access to the trial is easy and straightforward: participants simply click the link in the email invitation or in the court's digital case system to join.

d. Audio and video technology has long played a role in courts in civil cases, and courts have significant experience in this area, so it should be that many courts, detention rooms, and prisons are connected to a secure Judicial Video Service (LVP) network, which enables stable communication between and until the endpoint.

e. The use of audio and video technology in trials should be interpreted as increasing demand for justice services and as a response to the Covid-19 emergency.

f. To allow the criminal justice system to operate safely and flexibly during a pandemic, it is best if the substance of the regulations in the Perpu, which have become Law No.2 of 2020, regulates the provisions for the use of video in criminal jurisdictions. The use of video trials is always subject to judicial discretion. Videos are not used to run moral trials and major cases.

g. The court must release a report that estimates the use of audio and video technology in the trial category case by case a day or to some extent.

h. To open access to trials and justice services, courts should develop guidelines on how to connect to criminal trials using LVI available in the Supreme Court and publish short videos showing how to access the system. There are also online help numbers that offer technical support to trial attendees.

i. Over the coming months, we will continue to improve our approach to using audio-video alternatives during the coronavirus outbreak.

\section{CONCLUSION}

The presence of an online trial according to statutory regulations is invalid because the legal basis is under the law, potential the human rights violence, and obstacle burden of proof productions avoidance of law certainty. The weak side of the legality aspect of the online trial cannot be circumvented by the provisions of the Perpu and the law, because the politics of law do not want it to happen.

Nobody knows when the Pandemic will end, but law enforcement must continue. The government is obliged to have a proper legal basis and adequate facilities and infrastructure for teleconference hearings to ensure legal certainty and protection of human rights.

Perpu No. 1 of 2020 and KUHAP do not cover the rules for teleconference hearings, so a breakthrough is needed to make the special rules for the law provision of teleconference sessions or the Perpu of KUHAP which includes the overall revision.

Online trials are an option that must be pursued so that justice services are still fulfilled to the public. Defendants are susceptible to misleading trial practices.

To provide standard protection to the defendants, it is necessary to improve the mechanism with various procedures and facilities and infrastructure intended to implement the best legal practices in good faith that provide access to the widest possible justice services and protection of human rights according to the constitution. 


\section{REFERENCES}

[1] Sumali, "Penguatan Profesi Hakim Menuju Peradilan Modern Menurut MA RI," p. 4.

[2] Mahkamah Agung, Peraturan MA (Perma) No 1 Tahun 2019 tentang Administrasi dan Persidangan di Pengadilan Secara Elektronik. Pasal berkaitan Pasal 2 ayat (2), (3), (4) dan (5); Pasal 3; Pasal 4; Pasal 6; Pasal 7; Pasal 8; Pasal 9; Pasal 10; Pasal 11; Pasal 13; dan Pasal 16. 2019.

[3] A. Hamzah, Asas-Asas Hukum Pidana. Jakarta, 2006.

[4] B. Mannan and S. D. Arijanti, "Peraturan Pemerintah Pengganti Undang-Undang Dalam Perspektif Ajaran Konstitusi dan Prinsip Negara Hukum,” Ilmu Huk., vol. 4, no. 2, p. 226, 2017.

[5] R. C. Williams, "the One and Only Substantive Due Process Clause," Yale Law J., p. 422.

[6] J. Ashiddiqie, Konstitualisme Indonesia. Jakarta: Setjen MK, 2006.

[7] C. S. Pratiwi, "Tantangan Mewujudkan Sistem Peradilan Pidana Berdimensi HAM dan Court Excellence Di Era New Normal," 2020.

[8] D. F. Alisyahdi, "Peluang dan Tantangan ECourt Di Era New Normal," 2020.

[9] H. L. Packer, the Limits of the Criminal Sanction. California: Stanford University Press, 1968.

[10] Republik Indonesia, Undang-Undang No. 8 Tahun 1981 tentang KUHAP. 1981.

[11] S. A. Purnamawati, "Access to Justice for Marginal Groups as a Constitutional Right for Indonesian Citizens gets Justice and Equality before the Law," 2020, p. 6. 